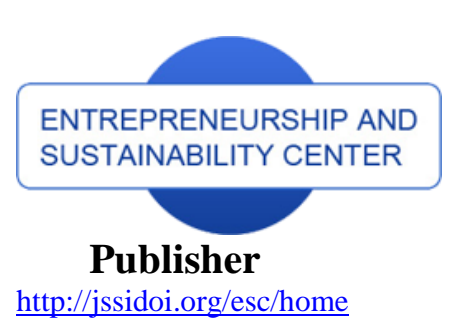

http://jssidoi.org/esc/home

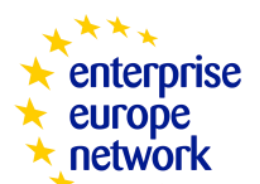

Business Support on Your Doorstep

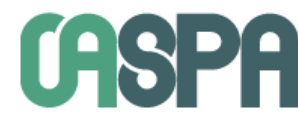

Scopus

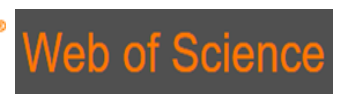

1 Clarivate

Analytics

\title{
THE PROCESS OF INDIVIDUALISATION OF PUNISHMENT IN INSOLVENCY CRIMES
}

\author{
Jozef Čentéš ${ }^{1}$, Michal Mrva², Michal Krajčovič ${ }^{3}$ \\ ${ }^{1,2,3}$ Comenius University in Bratislava, Šafárikovo nám. č. 6, Bratislava, Slovakia \\ E-mails: ${ }^{1}$ jozef.centes@flaw.uniba.sk; ${ }^{2}$ michal.mrva@flaw.uniba.sk; ${ }^{3}$ michal.krajcovic@flaw.uniba.sk
}

Received 25 March 2018; accepted 24 October 2018; published 30 December 2018

\begin{abstract}
In the context of considerations concerning justice in the punishment of criminal offenders it is necessary to focus on the issue of individualisation of the sentence. Through this process the court determines the offender's particular kind of punishment and sentence. The punishment should subsequently be an expression of society's idea of the state's fair reaction to the offence committed. The authors have focused on the process of individualisation of punishment in the case of sentencing offenders in insolvency crime. The theory of rational choice and ideals of restorative justice are of crucial importance in the authors' thinking. In reflection of the object of the criminal activity and the element of reciprocity (presuming rationality of the perpetrator) we come down to the suitability of the more common imposition of pecuniary penalty on these perpetrators. The text analyses both the advantages and disadvantages of pecuniary penalty, not just in relation to insolvency offenders.
\end{abstract}

Keywords: insolvency; insolvency crime; punishment; criminal liability; pecuniary penalty; individualisation of punishment

Reference to this paper should be made as follows: Čentéš, J.; Mrva, M.; Krajčovič, M. 2018. The process of individualisation of punishment in insolvency crimes, Entrepreneurship and Sustainability Issues 6(2): 603-619. http://doi.org/10.9770/jesi.2018.6.2(10)

JEL Classifications: K14

Additional disciplines: law

\section{Introduction}

Justice is an age-old human ideal, whose content has changed depending on the specifics of the particular stage of the cultural and historical development of human society. Over the course of these metamorphoses of society, not just the content of justice has changed, but also its position in the legal code of states of the continental legal system. The local legal system is based on elements of the Christian faith, Greek philosophy and Roman-law tradition (compare e.g. Kasinec, 2015). Celsus's statement that law is the art of goodness and equity (Ius est ars boni et aequi) is well known and it was Cicero who said that justice ensures that everybody gets what they deserve (Iustitia in suo cuique tribuendo certinur). There thus exists between justice and law and age-old bond, which seeks to achieve voluntary acceptance of law from the side of its subjects. 


\section{The International Journal}

ENTREPRENEURSHIP AND SUSTAINABILITY ISSUES

ISSN 2345-0282 (online) http://jssidoi.org/jesi/

2018 Volume 6 Number 2 (December)

http://doi.org/10.9770/jesi.2018.6.2(10)

Pinz succinctly states that "it is the very idea of justice that provides for the phenomenon of the right to respect and gravity" (Pinz, 2011) and for this reason, justice is "inextricably linked to law itself and it can be said that justice is the essence, the core of law, or an immanent category of law" (Cibulka et al., 2013). This bond between law and justice has become inextricable in the conditions of a material legal state, in which legal methods of regulating society dominate. Law in these terms is perceived as an instrument serving to fulfil a given ideal.

The value of justice, which has been given the form of legal principle upon its reception into the legal code thus became established in the legal codes of states having the continental legal system as a core constitutional principle (leading idea), representing the pillar of the proclaimed legal state. As a result of its presence in the material core of constitutions, it then feeds into all legal branches of the legal code and influences individual legal norms and legal institutes of these legal branches (including the way they are interpreted and applied). This concerns a core constitutional principle that should shine through into other legal regimentation, in particular that of a sub-legal nature, including implementing regulations, whilst such legal regimentation should also be interpreted in the light of the principle of justice. (Krajčovič, 2016). The above naturally relates in particular to the criminal law area, or (in the procedural sense) to criminal proceedings, as proceedings conducted in the purview of the Criminal Code, the purpose of which is: (1) to ascertain the offence and circumstances under which it was committed; (2) subsequent fair and expedient punishment of the offender; and (3) overall strengthening of citizens' trust in the state and authorities acting on its behalf (law enforcement agencies and courts) (compare Čentéš et al., 2012).

The requirement for justice (and the provision of adequate legal safeguards) is most often perceived particularly in relation to deriving responsibility for unlawful action (behaviour in society) especially in punishing the offender for committing a socially dangerous act classified as a criminal offence. The increased demand of society for preserving justice in criminal proceedings is given in particular by the "diversity" of the range of criminal sanctions and their sentences. The imposition and execution of the latter severely restricts the ordinary life of the offender, and this not just for the duration of the sanction imposed, but also after its execution (until the sentence is extinguished). It is on this basis that there rests the legitimacy of the requirement that the punishment imposed on the offender be neither inappropriately strict (Draconian punishment), nor formalistic - inappropriately mild. It is precisely this proportionality of derived repression that is the primary sign distinguishing retribution from revenge.

Both extremes of punishment are objectively unjust, jeopardising the achievement of the purpose of criminal prosecution. We define the purpose of punishment in accordance with $\S 34(1)$ of the Criminal Code as the protection of society against perpetrators by preventing a perpetrator from committing further criminal acts and creates the conditions for his correction in order that he lead an orderly life and concurrently discouraging others from committing unlawful acts; punishment also expresses the moral conviction of the perpetrator by society.

The need for proportionality was accentuated by Beccaria: The public interest is not only that crimes are not committed, but also that they are rarer. So obstacles that discourage people from crime must be stronger, to a degree that they are contrary to the public interest and correspond to the motive leading to committing the crime. The goal is therefore nothing other than to prevent a criminal from again harming citizens and to discourage others from doing the same. Punishments and the way in which they are imposed must be carefully chosen so that the punishment, once served, leaves a more effective and lasting impression on the minds of men and an impression less painful to the criminal's body (Beccaria, 2009).

Although thoughts of justice in a particular case are inextricably linked with the criterion of equality and equal (similar) approach to legal subjects in the same (similar) situation, there must not be confusion over the fact that crucial in searching for an answer to the question of who (or which perpetrator) deserves what in the particular 


\section{The International Journal}

ENTREPRENEURSHIP AND SUSTAINABILITY ISSUES

ISSN 2345-0282 (online) http://jssidoi.org/jesi/

2018 Volume 6 Number 2 (December)

http://doi.org/10.9770/jesi.2018.6.2(10)

case, is the actual individualisation of the imposed sanction. An individualised approach to each perpetrator is to ensure the fulfilment of the criterion of fairness of the punishment and in its content it expresses the level of the humanist approach to the perpetrator and the level of respect for his human rights. With this regard we agree with Henčeková, inspired by Fromm (Fromm, 2014), that for establishing justice it is not enough to set rules using purely logical, rational operations, but in these rules it is necessary to take into account primarily the person as a human being, which is not the opposite of a logical and rational approach, but is the boldest consequence of rationalism (Henčeková, 2017).

From the theoretical point of view it is necessary in this process to focus on (take into account) the relatively stable elements on which justice is based. The authors understand justice in its pluralistic sense and, in accordance with Schmidtz, recognise as relatively stable elements: reciprocity, merit, equality and need. (Schmidtz, 2015) Only on the basis of weighing the above elements can there be determined and given to each perpetrator that what is right to him.

From the practical point of view of criminal proceedings it is necessary to understand individualisation of punishment as the decision-making process of the criminal court conducted in the framework of the particular law-application process, in which there is a cumulative weighing (balancing) in particular of those facts relating to the perpetrator's deeds: the manner in which the offence is committed and its consequence (violation of or threat to a legally protected interest), culpability (intentional negligence), motive, aggravating circumstances, mitigating circumstances, personal and other (family, property, etc.) circumstances of the perpetrator and, last but not least, the possibility of reforming the perpetrator. Naturally, in certain cases it is necessary to reflect also other facts, e.g. the degree of co-perpetration, the form of participation in the criminal offence, the multitude of criminal activity or the developmental stage of the offence. Only in this way can it be ascertained what punishment and equally what scope of it will be fair, proportionate and legal in the individual case (compare Chovancová, 2017).

Criminal activity of a same type (economic, property, violent, etc.) has common implications for the process of individualisation of punishment. The object of criminal activity (legally protected interest, value) and the manner in which it is violated or threatened (the objective side of the subject matter) has an undoubted influence on the court's considerations regarding the area of fundamental human rights of the perpetrator that are to be affected by the sanction imposed. It thus represents a sort of guide in determining in what area of the perpetrator's normal life should suffer in the interest of fulfilling the purpose of punishment.

For the purposes of this study, we considered what common implications for the process of individualisation of sentences arise from the perpetrator having committed an insolvency crime that, in terms of the type of object, falls within the category of property crime. We particularly focus on the fact as to whether in terms of the reflection of the element (fairness) of reciprocity there can be identified the most suitable area of offender punishment that should be favoured in the process of individualisation of punishment. Naturally, accepting the possibility of considering a criminal prosecution, provided that the court can justify such choice accordingly.

The authors are of the opinion that generally the most appropriate alternative punishment imposed for committing any of the insolvency offences is pecuniary punishment, through the execution of which the perpetrator's property (asset values) is reduced. An important fact is that the state's claim from a legally imposed pecuniary penalty (from the legal point of view in the Slovak Republic) represents an intact (or untouchable) claim in the bankruptcy administration proceedings of a natural person. For such offences are punished in no small number members of statutory or other bodies of the bankrupt - legal person. Since the offender is required to pay (perform) the pecuniary penalty even though that the recovery of his other claims has ceased in consequence of a possible "declaration of bankruptcy", the inevitability of the punishment is thereby strengthened, and its essence 
lies in the fact that the timely detection of a crime and the imposition of a sentence should convince the perpetrator of the fairness and inevitability of the punishment not just in terms of the fact that it has been imposed, but also from the aspect of its probable execution, whereby it helps achieve the purpose of the punishment both at the level of repression and prevention (Kolesár, 2010). In comparison with the severity of the punishment, its inevitability acts to a much greater degree preventively ex ante (as regards potential perpetrators) as well as ex post (in the case of convicted and fairly punished offenders). This is the basic criminological fact we intend to take into consideration in the process of our reflections. It has to be noted, that M. C. Materni concludes likewise, in connection with Beccari's ideas in contrast to the ideas of Kant and Hegel, in his deep analysis of the theory of punishment. (Materni, 2013).

\section{Insolvency offences directed at enrichment}

For the purposes of this study, we focused on the group of insolvency crimes (in professional literature they are also referred to as bankruptcy crimes), that are of a property nature - their occurrence in society adversely affects another's property. Property crimes mean those offences having property as the primary subject matter. "Property is, alongside right of ownership, also other property rights, whilst criminal law protection applies also to the undisturbed possession of a thing. (...) Property means not just a thing, but also various property rights (e.g. claims)" (Mencerová; Tobiášová; Turayová et al., 2014).

The range of acts for which criminal sanctions may be imposed and aimed against property is not just diverse, but also numerous. In the Slovak Republic we understand property crimes as comprising in total 40 unlawful acts marked in the Criminal Code as a separate chapter. These are divided by legal doctrine (Mencerová; Tobiášová; Turayová et al., 2014) into 4 subgroups depending on the manner in which the perpetrators threaten or violate property rights:

- $\quad$ crimes of a property nature aimed at enrichment to the detriment of third-party property;
- $\quad$ crimes of a property nature aimed at damaging the property of another;
- $\quad$ crimes of a property nature directed at usurping utility (furtum usus); and
- $\quad$ crimes of a property nature aimed at preying on the criminal activity of another person.

Below we will devote our attention to the specific group of property crimes aimed at enrichment to the detriment of third-party property that have been committed in connection with insolvency proceedings or the bankruptcy of a debtor - bankrupt (de facto or pretended). We shall understand insolvency crimes as being synonymous with bankruptcy crimes. A specific feature of these acts is that in relation to the insolvency of a debtor the perpetrator through violating or threatening a legally protected interest sought to achieve benefit in his property integrity, or in the property integrity of another person. Benefit consists in a quantitative increase in asset values compared to the state prior to committing the crime or no diminishment of these values in consequence of fulfilling statutory or contractual duty that the perpetrator or other person was obliged to fulfil in connection with the solution of the bankruptcy (or its prevention). The result sought by the perpetrator in committing the given crime thus is to be, if generalising to the greatest possible degree, the influencing of the (quantitative, qualitative) property values of the perpetrator or of another person that are affected in the process of the collective arrangement of the bankrupt's property relations. Enrichment should be effected to the detriment of the property of another, most commonly a creditor's claim.

Insolvency crimes we will therefore take to mean those crimes of a property nature that threaten or violate the property of another (mostly of an obligation-legal nature) in connection with this, usually, emergency means of arranging the property relations of a bankrupt. Thus, we are referring to the definition of bankruptcy crimes according to Púry, who characterises them as crimes whose commission is related primarily to contractual legal 


\section{The International Journal}

ENTREPRENEURSHIP AND SUSTAINABILITY ISSUES

ISSN 2345-0282 (online) http://jssidoi.org/jesi/

2018 Volume 6 Number 2 (December)

http://doi.org/10.9770/jesi.2018.6.2(10)

relations between creditors and debtors, with the bankruptcy of the debtor and its solution in bankruptcy or restructuring proceedings and where their subject-matter is the protection of creditors' property interests in satisfying the receivables, the fair resolution of the debtor's bankruptcy and proper course of the bankruptcy and restructuring proceedings (Púry, 2015).

These crimes can be subsumed both under the category of property crime and under the category of economic criminality (although it is based on economic crimes). According to Strémy, for classifying these deeds under property or economic crime, besides the object of the offence and besides the manner in which the crime is committed (the manner of fulfilling the objective aspect of the subject matter) the person of the aggrieved is also relevant. Insolvency crimes fall under property criminality if a natural person is harmed and under economic criminality if a legal person is harmed (Strémy, 2010). We apply a different opinion to the above breakdown. What is significant is, in our opinion, the fact of the (non-)existence of the relation of the criminal activity to the business (economic) activity of the aggrieved and of the perpetrator and the state of the bankruptcy in which these subjects are found. An insolvency offence will, therefore, fall under economic crime even if a natural person entrepreneur is harmed by the deed. Irrespective of this issue, though, it is necessary to emphasise that insolvency crimes are always of a property nature (they violate or threaten the property of another) and for this reason we will analyse them in the context of the specifics of property crime.

The object of protection is specifically (directly or indirectly) creditors' claims that are to be collectively arranged as a result of bankruptcy. There is sought both the protection of creditors' claims (subject-matter) and concurrently also the protection of their enforceability. This is an ultima ratio means in relation to protecting the proper and timely achievement of the purpose of insolvency proceedings (bankruptcy, restructuring or consolidation). At the same time we state that not all insolvency crimes are aimed at enriching the perpetrator or another person, as we also indicate that crimes of a different nature (related offences) are committed in conjunction with insolvency crimes.

The essence of these related offences lies in the fact that from the time aspect they occur before the debtor goes into bankruptcy, they have a negative impact on the property situation of the creditor or debtor, or may be a consequence of the debtor's bankruptcy itself. Here we can mention in particular the offence of embezzlement, the offence of fraud, the offence of violating obligations in the administration of third-party property, the offence of distorting economic and commercial records, the offence of frustrating the execution of an official decision, the offences of tax and corruption crimes (L'orko; Smalik, 2017). It is necessary to pay special attention to corrupt behaviour in connection with insolvency proceedings, since the fulfilment of its purpose and the proper and lawful fulfilment of the obligations of entities involved in it are particularly jeopardised by such behaviour (Kováčiková; Kováčik, 2017). We therefore identify with Blažek's opinion that in the case of some of the mentioned group of crimes it is private-law corruption de facto without a formal legal indication as a corruption offence (e.g. machinations in connection with bankruptcy and settlement proceedings) (Blažek, 2017).

From the aspect of the objective side of the subject matter, the group of insolvency crimes is succinctly characterised by Beleš as crimes relating to the legal relations of creditors and debtors, the group object of which is the protection of creditors' property rights as well as the protection of the public interest in the lawful and proper course of insolvency proceedings; this concerns crimes relating to the bankruptcy of a legal person (fraudulent bankruptcy, culpable bankruptcy), crimes committed by debtors aimed at frustrating the satisfaction of a creditor (harming a creditor, favouring a creditor), violating obligations in the administration of third-party assets and crimes relating to frustrating the proper course of insolvency proceedings (machinations in connection with bankruptcy and settlement proceedings, frustration of bankruptcy and settlement proceedings) (Beleš, 2017). 


\section{The International Journal}

ENTREPRENEURSHIP AND SUSTAINABILITY ISSUES

ISSN 2345-0282 (online) http://jssidoi.org/jesi/

2018 Volume 6 Number 2 (December)

http://doi.org/10.9770/jesi.2018.6.2(10)

Property is therefore protected by these subject-matters against undiligent or fraudulent conduct of the bankrupt (culpable bankruptcy, fraudulent bankruptcy), against a breach of statutory or contractual duty to act in accordance with professional diligence (breach of obligations in management of third-party property) and the criminal-law protection also protects creditors' right to satisfaction of their claims in accordance with the principles of insolvency proceedings (favouring a particular creditor, frustrating bankruptcy and settlement proceedings).

It is therefore clear that the category of insolvency crimes, with the exception of the offence of violation of obligations in the management of third-party assets, is a subcategory of property crimes aimed at enrichment to the detriment of third-party property. In terms of penalisation proceedings, this concerns various deeds. Their commission leads to the exclusion or limitation of the diminishment of the bankrupt's property in the given proceedings (frustration of bankruptcy or settlement proceedings), but also the unlawful acquisition of property benefit in contravention of the principles of insolvency proceedings (favouring a particular creditor) in the collective arrangement of the bankrupt's property relations.

\subsection{Sociological background of the debtor's bankruptcy}

The sociological-legal context of the examined issue should not be overlooked. First of all we focus on the object of the perpetrator's attack - property. Property can be understood as chattels accumulated in connection with performing various activities in the course of human life, they may be acquired through donation, other means of alienation or inheritance. Most commonly, the source of property is the work effort of an individual in the form of performing paid work or business activity. It may also be acquired by a repaid loan, in which a person undertakes to repay a borrowed amount of money with interest at set due dates.

Regardless of the method of acquisition, the amount of property values influences an individual's purchasing power - the ability to satisfy subjective needs at a particular moment by procuring goods and services for accumulated property values. Besides this, property is a significant part of an individual's social status and therefore fundamentally determines his social standing. It is on this basis that the legitimacy of the protection of property rights (values) by criminal law standards rests.

Besides things, property comprises also claims and other asset values that are most frequently a subject of attack in insolvency crimes. Claim must be understood as a subjective right of a creditor to the provision of a certain performance from a debtor, to which there correlates the debtor's obligation to provide such performance. An individual in the course of his life enters into myriad legal relations, from which he incurs subjective rights and obligations. In these relations he holds the status of creditor or debtor, and in synalagmatic relations is concurrently a creditor and debtor to another contracting party. With regard to the fulfilment of contractual obligations, in international and national law there is established the principle of pacta sunt servanda, which seeks to preserve certainty in obligation-legal relationships. According to this guiding idea, it is necessary that what the legal entity agreed on be fulfilled. The co-contractor fairly and legitimately relies on the provision of such performance.

The belief that the ideal state is achievable when all obligations cease through the fulfilment of the contracting parties' obligations (solution), is undoubtedly utopian. For objective or subjective reasons, the contracting parties fail to fulfil their obligations properly and on time. As a result the contracting partners' claims mature when this subjective right of the creditor to the provision of the mentioned performance is enforceable. Claims arisen may be individually sued for and performance can be claimed at court. In the case of success at court the creditor may initiate enforcement action to the detriment of the debtor. This is an individual way of recovering a creditor's claim. 
The number of liabilities of a particular legal or natural person is, in today's globalised world, not limited and therefore this burden can, particularly in the course of doing business, often become unsustainable. A debtor thus gets into bankruptcy - a state of insolvency or overindebtedness. It is an objective condition that occurs independently of the will of the subject at the moment when the necessary legal pre-requisites arise; a fundamental requirement being a plurality of creditors (Žitňanská; Ovečková, 2013). The debtor is required to avoid bankruptcy and in the impending occurrence of bankruptcy the debtor is required to promptly take appropriate and proportionate measures to avert it (§ 4(1) of the Act on Bankruptcy and Restructuring). If a debtor is actually entering bankruptcy, the legal code of the Slovak Republic provides for the institutes of bankruptcy, restructuring and consolidation, as a collective way of arranging the property relations of debtors - bankrupts, in the legal codes of the European Union (naturally with certain modalities).

In the case of a debtor's bankruptcy, this is a fairer and more timely way of the collective recovery of creditors' claims in comparison with their individual efforts to achieve enforcement in execution proceedings, where in satisfying creditors' claims there applies the principle of priority (supplemented by the principles of priority and proportionality). We can perceive insolvency proceedings also as proceedings in which there is a collision of interests of the parties involved, and this not just between the debtor and its creditors, but also mutually between creditors themselves. In this model there is the place of the administrator, who in insolvency proceedings equally has his own subjective interests. The parties to these proceedings endeavour to satisfy their interests in these proceedings to the maximum extent possible. It is no surprise that in the collision of such interests it is tempting for the parties involved to not proceed in a standard - lawful manner, mostly for mercenary motives.

We therefore analyse criminal activity in insolvency proceedings in the context of economic models of crime, where the perpetrator presumably considers the advantages and disadvantages of fulfilling a legal obligation and, on the other hand, the benefits and risks of unlawful conduct that would grant him a relatively great satisfaction of its receivables or similar property benefit. Neither should there be omitted reflections regarding legalpsychological starting points to the examined issue, since these are arguments relevant for the considerations of the court in individualising punishment. In accordance with Gábriš we see the consideration of psychological knowledge in combination with findings from other sciences as an instrument for the correct understanding of the reasons and external as well as internal factors influencing human decision-making, where this knowledge is intended to ensure greater effectiveness of the law in its prescriptive mission.(Gábriš, 2017).

\section{Criminal law consequences of insolvency crimes}

We approach our reflections regarding the suitability of alternative punishment imposed on perpetrators of insolvency crimes. On the basis of rational consideration, for the process of individualisation of punishment we recommend the most suitable area of prosecution of such perpetrators, provided that other facts, in particular the perpetrator's legitimate needs, do not necessitate a different area of recourse against his human rights.

Before the consideration itself, it must be borne in mind that the consequences of unlawful conduct represent a threat that should deter a potential perpetrator from committing it. In crime prevention this concerns a scientifically justified, deliberate, purposeful, planned and coordinated action on the causes and conditions of criminality with a view to eliminating them, potentially through a suitable selection of methods and forms to at least in part eliminate and concurrently support the creation of anti-criminogenic conditions. (Holcr et al., 2011; Zoubková et al., 2011). This is the preventive effect of criminal law repression (ex ante) and any deterrent effect is necessarily linked with the threat of statutory enforcement - represented by a sanction and the procedural-law enforcement procedure of its imposition and recovery. 


\section{The International Journal}

ENTREPRENEURSHIP AND SUSTAINABILITY ISSUES

ISSN 2345-0282 (online) http://jssidoi.org/jesi/

2018 Volume 6 Number 2 (December)

http://doi.org/10.9770/jesi.2018.6.2(10)

Sanctions should, therefore, always be selected in such a way that legal norms regulating social relations are as effective as possible, in order that the objective pursued by legal norms can be fulfilled. It should be borne in mind that legal norms are issued for the purpose of regulating social behaviour (Allott, 1981), whereby the selected method of regulation has a significant impact on the subsequent effectiveness of those legal norms. If legal norms are to be effective, the lawmaker cannot proceed arbitrarily, but the chosen method of regulating social relationships must be the result of rational reasoning that is to be proposed in relation to the given criminal activity. Sanctions imposed (not just) by courts for a violation of an effective legal regulation must be chosen equally rationally. The social effectiveness of law is not just dependent on the degree of the deterrent threat of a potential sanction, but also on other factors that must unconditionally be taken into account in individualising sanctions. Sociological approaches to law have pointed precisely to this phenomenon. This, however, does not mean that the type of sanction and its intensity are irrelevant in relation to the violation of the law (M. m. Večeřa; Urbanová, 1996).

In connection with the issue of the effectiveness of a law, Večeřa and Urbanová identify a range of circumstances influencing its effectiveness, namely (1) the nature of the regulated social relations (where this points to the difficulty of regulating social relations outside the framework of social control); (2) the quality of laws (their unambiguity and understandability); (3) the stability of the legal code (in order that there are not overly frequent changes in valid and effective law); (4) the frequency of the violation of law (suffering a violation of legal norms causes social disintegration); (5) the quality of law enforcement agencies; (6) the respect in which the law and lawmaker are held; (7) the relationship of law and extra-legal social norms (the consistency or conversely inconsistency of these normative systems); (8) the level of legal awareness. These circumstances, in the authors' opinion, have an impact on whether a legal standard will be effective or ineffective (Večeřa; Urbanová, 1996).

There cannot be omitted the issue of legal awareness, as an intermediary act between the legal norm and lawful conduct of a social subject. Even if legal regulation of social relations derives from the existence of the irrefutable legal presumption that everybody knows the valid law (and ignorantia iuris neminem excusat), sociological surveys have confirmed that this presumption is not based on reality and many subjects commit illegal conduct precisely in consequence of not knowing the valid and effective legal regulation. An important intermediary variable between law and the actual behaviour of an individual is therefore legal awareness, which in professional literature is characterised "as a complicated, internally structured social phenomenon based on elements of knowledge of law, social legal ideas, on concepts of valid law and on concepts of ideal law" (Bakošová; Vaculíková, 2003). For this reason we must not overlook the need for correct and suitable communication of the content of legal norms to their addressees, since the level of legal awareness is another prerequisite for the effectiveness of a legal norm. Appropriately chosen sanctions may have a not insignificant impact on the level of legal awareness among the addressees of legal norms.

It may reasonably be assumed that in the case of persons seeking to gain advantage in the form of unjustified property benefit in connection with a debtor's bankruptcy, this interference in their property sphere represents a subjectively significant infringement of their rights. In insolvency proceedings the property benefit is achieved prevailingly at the detriment or harm to others' claims. In consequence of the perpetrator's criminal focus, it may reasonably be assumed that particularly these perpetrators will consider pecuniary punishment penalising their property integrity to be a punishment that will deter them from this criminal activity.

With the above there is inevitably connected with the application of elements of restorative justice (by way of social corrections). It is this approach that ensures achievement of the purpose of punishment concurrently with the necessary rehabilitation and reintegration of the perpetrator into an environment in which he has with 


\section{The International Journal}

ENTREPRENEURSHIP AND SUSTAINABILITY ISSUES

ISSN 2345-0282 (online) http://jssidoi.org/jesi/

2018 Volume 6 Number 2 (December)

http://doi.org/10.9770/jesi.2018.6.2(10)

members of society diverse social relations that were affected in consequence of the crime. We agree with Strémy and Klátik on the issue of the suitability of increased use of strategies with a reintegration effect on the perpetrator, since the perpetrator will again successfully re-enter ordinary life, begin working normally and produce material value for society (in particular through gainful activity), a benefit for society and for the perpetrator himself. This goal, though, primarily depends on the choice of methods, means and procedures that enable a successful re-socialisation process outside the prison environment (Strémy; Klátik, 2018). The decision as to what particular means of rehabilitation is, though, dependent on facts described in the first chapter.

Many theories devoted to the issue of criminal behaviour work from the assumption of a rationale choice by the perpetrator, who weighs the potential benefit from a criminal act in relation to the possible punishment that may follow in the event of his conviction for committing it. Both Beccaria and Bentham have identified the relation between these variables. The utilitarianist Bentham worked from the assumption that it is the benefit from the criminal act that is a driving force and a motive for committing an offence, whilst fear from possible punishment is a force that should discourage a person from unlawful conduct.

But Beccaria and Bentham are not fathers of the theory of rational choice. They are representatives of relative theories of punishment, according to which punishment should not just be a form of retaliation for the perpetrator, but should also have other social goals (purposes). Relative theories are based on the principle of "punitur, ne peccetur", according to which punishment exists so that no evil be committed (Urbanová, 2006). In the given case this concerns a deterrent theory that is based on the assumption of a certain rationality on the side of the potential perpetrator of the offence, meaning that if the threatened punishment for committing an offence is sufficiently strict, many potential perpetrators are demotivated from committing it.

If the punishment is mild, it will mean that the potential perpetrator will be rather more willing to assume the risk that this punishment will potentially be imposed on him. Modern deterrent theories no longer reckon just with the threat of formal sanctions, but take into account also informal sanctions, which can concurrently act deterrently on the certain perpetrators in relation to potentially committing an offence (moral conviction from side of society, the conscience of the perpetrator himself). Other variables, though, that can have an effect on the perpetrator's decision as to whether he commits the offence or not, remain unaffected.

These incomplete ideas were later complemented by economic models of criminality. Despite the fact that they cannot fully explain many crime-related phenomena (e.g. recidivism), they are of some benefit to the issue examined. In the models in question, there are detailed the kinds of advantages, gains or benefits, as well as the disadvantages, costs and losses that perpetrators of criminal acts achieve through committing them, and on the basis of weighing them they decide as to whether they commit the act and undertake the risks of the possible consequences or not. The advantages and disadvantages depend on the kind of offence and the perpetrator's personality, whilst where this concerns advantages, in some cases it is monetary gain, in other cases it is psychological benefits, such as satisfying a craving or sense of excitement from danger, etc. As regards disadvantages, these may include, in particular, direct material costs associated with the preparation and commission of the crime (e.g. purchasing weapons, equipment, etc.), furthermore there are psychological disadvantages (e.g. fear, anxiety, guilt, etc.), but also punishment and costs and consequences connected with it (whether direct or indirect, formal or informal).

In relation to the examined issue of insolvency crimes, they can be considered as beneficial may be considered the direct material gain consisting in minimising or completely eliminating the consequences of bankruptcy (insolvency or over indebtedness) on the property integrity of the bankrupt - for the perpetrator's current and future property values, or in eliminating the satisfaction of the debtor's liabilities by way of fraudulent 


\section{The International Journal}

ENTREPRENEURSHIP AND SUSTAINABILITY ISSUES

ISSN 2345-0282 (online) http://jssidoi.org/jesi/

2018 Volume 6 Number 2 (December)

http://doi.org/10.9770/jesi.2018.6.2(10)

pretence of bankruptcy. This direct material gain (procuring unjustified benefit) may consist, inter alia, in affecting the legality of:

- $\quad$ asset management in insolvency proceedings (including the process of identifying seasonable assets concealing property; stating false information in the list of assets and liabilities);

- the process of monetising the bankrupt's assets,

- $\quad$ satisfying creditors' receivables from the bankrupt's assets (in terms of the amount and priority);

and also in

- causing a state of bankruptcy in the interest of frustrating a creditor's satisfaction;

- frustrating a creditor's satisfaction by removing assets, encumbering a certain movable or immovable asset, by assignment of a receivable or by assumption of a debt, etc.;

- $\quad$ applying a non-existent right (claim) against a debtor of another creditor, in consequence of which its satisfaction is frustrated;

- favouring a creditor, with subsequent frustration of the satisfaction of another, earlier creditor;

- private law corruption - machinations in connection with insolvency proceedings;

Disadvantages include criminal sanctions and other sanctions, including social defamation and costs connected with criminal proceedings (in particular legal defence). From categories other than criminal law sanctions this primarily concerns sanctions in the framework of insolvency proceedings - for example failing to provide cooperation in ascertaining assets in bankruptcy proceedings. In terms of economic models of criminality, a perpetrator acts judiciously and rationally, selects and considers whether he will commit a criminal act or not, by analysing potential benefits and costs (Eide, 1973). Even though these models fail to explain the causes of committing many kinds of criminal acts, in relation to insolvency crime, their significance is indisputable.

From among the economic models, it is necessary to mention in particular the theory of rational choice, which came into criminology, sociology and other sciences via economics (where it was used to analyse, for instance, the potential behaviour of customers in a market). By means of the theory of rational choice, one can understand human behaviour (Green, 2002). At the level of criminal law, it can be argued that, in contrast to deterrent theories, it takes into consideration not just formal and informal forms of sanctions, but also many other factors that influence individuals' specific behaviour. The essence of this theory is that individuals rationally choose how to behave on the basis of an analysis of potential benefits and costs associated with the selected behaviour. Its attention is, therefore, not focused on social, cultural or biological factors having an impact on human behaviour. It focuses on the costs and benefits associated with a particular model of behaviour by a given subject, Whereas these are always relevant when considering crimes directed at enriching the perpetrator, including insolvency crimes.

The theory of rational choice, while it does not count on full rationality of an individual, taking into account all possible factors and their significance, it does nonetheless work from the assumption that an individual prior to committing the deed itself weighs up the pros and cons associated with the particular conduct (naturally only those he is aware of). Within the theory of rational choice it is possible to consider not just the determinants of a particular person's conduct, but also how these determinants can be influenced, in particular by way of:

a) increasing costs (cons) associated with committing a crime;

b) increasing the benefits (pros) associated with not committing a crime;

c) reducing the advantages gained from committing the offence;

d) reducing the cons associated with complying with the applicable law. 


\section{The International Journal}

ENTREPRENEURSHIP AND SUSTAINABILITY ISSUES

ISSN 2345-0282 (online) http://jssidoi.org/jesi/

2018 Volume 6 Number 2 (December)

http://doi.org/10.9770/jesi.2018.6.2(10)

The application of the theory of rational choice can also contribute significantly to suppressing the unlawful behaviour of individuals. In relation to the analysed issue of insolvency crime, it is perhaps most necessary to reflect on the appropriateness of sanctions imposed by courts and prescribed by law, since an effectively selected sanction (in terms of kind and scope) is an elementary precondition for individual prevention in the case of a given perpetrator. The criminal-law sanction is, thus, the primary disadvantage in the process of a perpetrator's considerations regarding unlawful enrichment at the detriment of third-party property. These disadvantages must then be appropriately communicated in relation to (potential) perpetrators so that they recognise the disadvantages of their conduct, otherwise the achievement of the desired change in behaviour is jeopardised.

It may be concluded that whereas traditional criminological and sociological concepts build on the conditionality of human behaviour with socialisation and the social environment of the individual, economic models are built on faith in the rationality of the individual, who is contemplating committing a crime. Their significance, though, lies not just in enabling understanding of the causes and reasons that led the perpetrator to commit a crime, but lies also in the field of criminal law or regulation. The authors see the importance of economic models in the fact that they perceive economic analysis to be a further circumstance that may impact the effectiveness of a law. The focus and intensity of a potential sanction recourse against subjective rights is another circumstance conditioning the effectiveness of legal regulation. The given variable is reckoned with particularly by perpetrators of deliberate crimes aimed at enrichment. It cannot under any circumstances be regarded as negligible, since "... that what in the end result motivates people in a proactive approach to fulfilling obligations imposed by law (in favour of the general good) is the very threat of sanction - harm, the burden of which a person feels also subjectively in ordinary life. Nonetheless, a person is, though free and can voluntarily decide to bear consequences associated with unlawful conduct. Therefore, the consequence of unlawful conduct should always be less favourable in comparison with the „price“ of fulfilling the statutory duty" (Čentéš, Krajčovič, 2016).

In the spirit of the theory of rational choice, we reflect on the implications of the reciprocity element for individualisation of (alternative) punishment for an insolvency crime committed.

\section{Reflection of reciprocity in the individualisation of punishments for insolvency crime}

We can summarise the above in that efficient punishment evokes a result that the convicted person selects available forms of satisfying their needs and excludes their satisfaction in ways contrary to legitimate needs, interests and goals. Through the correctional effect of criminal justice, the perpetrator is re-educated, his legal awareness and legal knowledge is increased and naturally the level of his legal socialisation is affected.

We are of the opinion that in insolvency crimes (aimed at enrichment) an effective alternative punishment (from the aspect of repression and prevention) is pecuniary punishment. This criminal law sanction of a property nature, achieves identicality between the field of the recourse against the perpetrator and the field in which the benefit from the criminal activity was to have been gained. Imposing and executing punishment in fact achieves the diametrically opposite effect from that which the perpetrator of the conduct intended. Instead of economic benefit, there is a reduction in the perpetrator's property (harm to his property values). It is precisely this form of reciprocity that we perceive to be crucial to fulfilling the purpose of criminal law repression.

In agreement with Schmidtz we perceive this reciprocity to be a core element of justice. Schmidtz sees it in a positive sense as a basic bond, the glue of a good community of people and also as an assessment criterion of the basic structure creating an environment in which there occur everyday exchanges of reciprocal dealings. (Schmidtz, 2015) Reciprocal relations represent an example of an ideal society. What is important is that mutuality conditions the nature of response to the occurrence of a certain phenomenon that is the cause of a 


\section{The International Journal}

ENTREPRENEURSHIP AND SUSTAINABILITY ISSUES

ISSN 2345-0282 (online) http://jssidoi.org/jesi/

2018 Volume 6 Number 2 (December)

http://doi.org/10.9770/jesi.2018.6.2(10)

given consequence. The primary phenomenon is the offence and the nature of reciprocal approach is conditioned by the specificities of this primary phenomenon, the occurrence of which raises the need for a response from society and the state.

We agree as well with Svatoš (Svatoš, 2014), that just knowing the causes of a certain phenomenon is a prerequisite in order that in future the person deliberately evokes or facilitates the emergence of such phenomena that have proved to be beneficial to him and conversely that he be deliberately prevented or restricted or impeded the occurrence of such phenomena that have proven unfavourable for him. The reciprocal approach influences the subjective sensibility of the sanction imposed, whereby the preventive-correctional action on the perpetrator is maximised, whilst in the case of pecuniary punishment the repressive function and the corrective function are fulfilled concurrently (Kolesár, 2010 and Strémy; Klátik, 2018). And it cannot be overlooked that often it is this reciprocity of punishment that matters more to the aggrieved than the damage compensation itself. It needs to be stated that it is certainly not possible, at today's level of cultural and historical development, to speak of reciprocity in the spirit of Hammurabi's axiom "an eye for an eye, a tooth for a tooth", although reciprocity has limits to its acceptability.

Even in this negative meaning (at the level of punishing unlawful conduct) reciprocity is a fact that can ensure good life in society. The given approach in individualising punishment, naturally following mutual reconciliation with other elements of justice is capable of fulfilling primarily the preventive-corrective function of criminal law.

As has been mentioned, in insolvency crimes, what is essential is the legitimate protected interest (value) that was jeopardised or violated by the perpetrator. In the case of intentional insolvency crimes, this is not an arbitrary conduct by the perpetrator. It is conditioned by various factors that have activated the perpetrator toward the illegal act.

From the legal-psychological point of view there are specific causes for each behaviour of an individual. The initial moment for influencing behaviour is the feeling of a certain deficiency and subsequent awareness of a need to obtain the lacking object, lacking value. The underlying cause of a certain behaviour in a particular situation is therefore a need and its objective is to satisfy it. Through the activation of the need in awareness (recognition of the need) the need transforms into an interest, which in contrast to the need, is now specifically oriented. An important and indispensable role in this process is played by values, or the value orientation of the personality. These perform the role of some sort of lead or mediating link between the directional and target component of motivation, the motivation process toward conduct (Houbová et al., 2008).

"The target represents the concluding, and in linear sequence, the last significant motivational variable. It concludes and fulfils the meaning of the whole process; it represents the ideal result of anticipation of the activity (...) Through achieving the goal, the need is satisfied (...) the state of the organism becomes relatively balanced" (Houbová et al., 2008).

The motivational process preceding the perpetrator's action must be reflected in the framework of considerations regarding reciprocity and the effectiveness of punishment. If the starting point for the perpetrator's action was a sense of lack of property integrity and the need to acquire the lacking object (enrichment at the expense of the bankrupt's estate or his creditor), even at the cost of committing an unlawful act, so it is rational and effective that the sanction impacts directly on this area. This identicality of the area of recourse against the perpetrator with the area in which benefit from the criminal activity should have occurred, will enable the fulfilment of the preventivecorrective function of criminal law - signalling the economic disadvantageousness of the unlawful act. In connection with this punishment, Mencerová has stated that "the property nature of pecuniary punishment makes from it a means for achieving the purpose of punishment, particularly in cases where the perpetrator has 


\section{The International Journal}

ENTREPRENEURSHIP AND SUSTAINABILITY ISSUES

ISSN 2345-0282 (online) http://jssidoi.org/jesi/

2018 Volume 6 Number 2 (December)

http://doi.org/10.9770/jesi.2018.6.2(10)

committed an offence of a property nature." (Mencerová; Tobiášová; Turayová et al., 2013). Strémy and Klátik likewise identify with this opinion and state that its imposition comes into consideration particularly in the case of property and economic offences, in the case of offences against public order and generally dangerous offences (Strémy; Klátik, 2018).

The sanction will be subjectively perceivable and, in the realm of rational choice theory, will signal the disadvantageousness of the offence for the perpetrator. It will be achieved through the harm to the perpetrator's property integrity in consequence of accepting the interest of satisfying a certain material need by means of criminal activity. This area of the perpetrator's life will, from the quantitative aspect, get into a more adverse state for the perpetrator, leading him to recognise the need to satisfy property needs solely in approved ways. The corrective effect will be achieved through the identicality of these two areas and, for this reason, it is appropriate to impose precisely a pecuniary punishment (as an alternative punishment), either alone or alongside another punishment.

The above is acknowledged also by the lawmakers of the Slovak Republic, when by means of $\S 56(1)$ of the Criminal Code they state that "Pecuniary punishment may be imposed by the court in an amount from $€ 160$ to $€$ 331930 on a perpetrator of an intentional offence by which he gained or attempted to gain property benefit" and only paragraph 2 of that section mentions the possibility of imposing a pecuniary punishment also for offences other than property crime. A court may impose a pecuniary penalty without the conditions referred to in section 1 being fulfilled, if it imposes the penalty for a misdemeanour and, having regard to the nature of the misdemeanour committed and the possibility of the perpetrator's correction, it does not impose a custodial sentence (compare Burda; Čentéš; Kolesár; Záhora et al., 2010). Naturally, the amount of the pecuniary penalty does not depend on the property benefit obtained or intended, and this may even exceed the pecuniary penalty. It needs to be stated that the amount of a pecuniary penalty should depend on whether a reparations sanction has concurrently been imposed (not necessarily in criminal proceedings). If a pecuniary penalty is imposed alongside compensation for damage caused, then it should be milder than in the case where it is not possible to impose damage compensation, and the benefit from the criminal activity is drawn off by way of the pecuniary penalty. Its individual differentiation should be designed also so that (separately or in combination with damage compensation) the perpetrator's property integrity becomes more unfavourable than it was before committing the criminal offence. Even despite the fact that in $\S 56(1)$ of the Criminal Code this is a classical and not teleological norm, the purpose pursued by the legislator must be fulfilled in the decision-making activities of criminal courts. It is possible to diverge from this will only if there exist reasons (legitimate needs of the perpetrator) for imposing other punishments (e.g. compulsory labour, etc.). If we work from favouring ideals of restorative justice, we must prioritise punishment not connected with custodial sentencing, unless this is necessary. For the area of criminallaw recourse against insolvency crimes committed for mercenary motives, this implies the appropriateness of imposing pecuniary penalty or other appropriate alternative punishment.

One factor excluding the imposition of this alternative punishment is primarily its unenforceability - the situation when the current and (likely) near-future property situation of the perpetrator does not allow for the execution of a pecuniary penalty either at all or only at the detriment of jeopardising the perpetrator's basic existential needs. Pecuniary punishment always affects not just the perpetrator himself, but also his family and close persons. This fact cannot wholly be excluded and makes the imposition of a punishment unacceptable only in the case of disproportionately severe impacts on persons financially dependent on the perpetrator. Pecuniary punishment likewise cannot be imposed in the case where this would lead to frustration of the aggrieved party's claim to damage compensation caused by the criminal offence.

In considering the enforceability of pecuniary punishment, it must be borne in mind that it needn't be made in a single payment, but it is permissible that it be paid in regular monthly instalments (on the basis of a court order). 


\section{The International Journal}

ENTREPRENEURSHIP AND SUSTAINABILITY ISSUES

ISSN 2345-0282 (online) http://jssidoi.org/jesi/

2018 Volume 6 Number 2 (December)

http://doi.org/10.9770/jesi.2018.6.2(10)

This procedure is justified by the amount of the pecuniary punishment imposed and by the perpetrator's personal and property situation. Under the legal code of the Slovak Republic, the court determines the amount and maturity of instalments, in a length of at most one year from the sentence entering into force. In this way even a convict with little property is given an opportunity to voluntarily pay the imposed pecuniary punishment within his possibilities in the form of regular instalments. At a minimum amount of punishment spread over 12 regular monthly instalments, this represents a monthly payment (regular net penalty) of $€ \mathbf{1 3 . 3 3}$, which in today's macroeconomic situation and labour market situation makes the given alternative punishment acceptable for most perpetrators. Payment of a pecuniary punishment in monthly instalments is admissible particularly in cases where payment of the whole pecuniary punishment would, in view of the convict's property relations, be inadmissible, though where the perpetrator's situation makes it possible that the penalty be paid in instalments.(Čentéš et al., 2015). The pecuniary punishment should, therefore, be an expression of the convict's possibilities and capabilities. The possibility of its payment in regular instalments, from the theoretical aspect, ensures also equality before the law - that the perpetrator's creditworthiness does not influence the (im)possibility of an alternative solution to the criminal case.

Last, but not least, as has already been mentioned, pecuniary punishment is an effective instrument of punishment, also for the reason that in the case of a natural person's financial reconciliation, this represents an intact claim, and the perpetrator is not relieved of it in this way. The recoverability of certain receivables in the reconciliation process lapses, though the above does not apply in the case of pecuniary penalty claims (particularly in the case of its settlement in regular monthly instalments). The subjectively perceivable harm is thus felt by the perpetrator even despite any declared bankruptcy. The imposition of pecuniary penalties thereby motivates perpetrators to economic activity, whereby they are not enabled to avoid fulfilling them without actually feeling the infringement on their rights.

\section{Conclusion}

In this study we focused on the individualisation of punishments in the case of those insolvency crimes aimed at enrichment of the perpetrator. This group of unlawful acts is linked with the state of the debtor's bankruptcy and the collective settlement of his property relations, particularly those of an obligation-legal nature (claims). It is not uncommon for perpetrators, for mercenary motives, to attempt to avoid fulfilling their statutory duties in connection with solution of a bankruptcy (either their own or that of another debtor). When the perpetrator commits any of the above mentioned criminal acts, it is a sovereign right of the state to punish him fairly. Fair punishment is primarily proportionate punishment that is concurrently both expedient and effective.

When it comes to the question of fairness of punishment, one has to consider the elements of which justice (in terms of fairness) consists. With this regard, the authors have analysed the fairness of punishment in accordance with Schmidtz's theory of justice. According to this theory, justice (fairness) consists of reciprocity, merit, equality and need as its relatively stable elements and only on the basis of weighing the mentioned elements can one determine and give to each perpetrator what he deserves - a fair (and proportionate) punishment. All of these elements should thus be kept in mind by judges of criminal courts, who individualise the punishment in insolvency crimes (and other crimes as well). In case of insolvency crimes, it is necessary to focus on the element of reciprocity, which reflects the fact that the perpetrator has targeted the property of others with his criminal behaviour.

In the interest of choosing an appropriate type of punishment and its scope, while preserving the ideals of restorative justice, it is necessary to clarify in detail all relevant circumstances of the case in the process of individualising the punishment by the criminal court. On the basis of the correct methodological procedure in 
The International Journal

ENTREPRENEURSHIP AND SUSTAINABILITY ISSUES

ISSN 2345-0282 (online) http://jssidoi.org/jesi/

2018 Volume 6 Number 2 (December)

http://doi.org/10.9770/jesi.2018.6.2(10)

specifying the criminal-law norms for specific cases there should subsequently be selected a punishment fulfilling the above-mentioned attributes, which naturally in a legal state also include legality (of the punishment).

The authors work from the basis of the appropriateness of imposing a pecuniary punishment as an alternative punishment for insolvency crimes committed for a mercenary motive. We reach this conclusion on the basis of the theory of rational choice, presuming a greater degree of (economic) rationality of perpetrators of property crimes. If a perpetrator voluntarily satisfies his needs in an unlawful manner, it is necessary to accentuate to him the severity of the result of violating the law (and legitimate values protected by it), and this severity should be subjectively perceptible. If a pecuniary penalty is imposed, there arises to the perpetrator suffers the diametrically opposite effect from that which he intended to achieve through his criminal activity. Recognising this fact facilitates individual prevention, since the perpetrator will pro futuro select ways of satisfying his subjective needs, from fear of recurring punishment, what is perceptible. These reflections must also include the standing of pecuniary punishment in reconciliation proceedings, where this concerns an intact legal claim that does not lapse in the given proceedings. The above contributes to the irreversibility of the punishment, conditioning its effectiveness. We therefore view the more frequent imposition of pecuniary penalty as an effective tool for preventing the occurrence of unlawful conduct in connection with the insolvency of a particular person and its solution.

In the interest of fairness of punishment, the level of punishment must be individualised so that it is proportionate. Where the benefit from the criminal activity is drawn off by the punishment, it should be individualised in a greater scope in comparison with its imposition alongside the obligation to pay compensation to the aggrieved party. It is precisely its appropriateness that conditions the subjective perceptibility of the punishment (the subjectively felt repression), that should signal to the perpetrator the disadvantage of violating the law. In the process of individualisation in the interest of personality and enforceability of the punishment, it is always necessary to consider whether the convict should pay it in a single sum or in regular instalments.

The individualisation of punishment for insolvency crimes is thus a complex and complicated process and undoubtedly a challenge for criminal courts. In this study we have expressed our opinions in favour of imposing pecuniary punishment (as one of the alternative punishments), while our methodological starting points and considerations, we hope, will serve in application practice as some sort of guide in decision-making in the given criminal cases.

\section{Aknowledgements}

This research was supported by the project "Guidelines and tools for effective elimination of unlawful acts in relation with potential insolvency", which has received funding from the Slovak Research and Development Agency under the contract No. APVV-15-0740

\section{References}

Allott, A. 1981. The Effectiveness of Laws. Valparaiso University Law Review, 15 (2), $229-242$. https://scholar.valpo.edu/cgi/viewcontent.cgi?article=1579\&context=vulr

Bakošová, E.; Vaculíková, N. 2003. Základy sociológie práva [Fundamentals of the Sociology of Law], Bratislava, Slovak Republic: Comenius University in Bratislava, Faculty of Law, Publishing Department.

Beccaria, C. 2009. O Zločinoch a trestoch [On Crimes and Punishments]. Bratislava, SR: Kalligram.

Beleš, A. 2017. Komparácia právnych úprav insolvenčných trestných činov na Slovensku a v Rakúsku [A Comparison of legal regulations for insolvency crimes in Slovakia and Austria], Acta Facultatis Iuridicae Universitatis Comenianae, 36 (extraordinary issue). 
Blažek, R. 2017. Corruption as a Cause of Insolvency, Acta Facultatis Iuridicae Universitatis Comenianae, 36 (extraordinary issue).

Burda, E.; Čentéš, J.; Kolesár, J.; Záhora, J. et al. 2010. The Criminal Code. General part. Brief comment. Prague, Czech Republic: C.H. Beck.

Čentéš, J. Et Al. 2015. The Criminal Code. Large comment. 2. updated edition. Bratislava, Slovak Republic: EUROKÓDEX.

Čentéš, J. Et Al. 2012. Criminal procedural law. General and special section. 2nd edition. Šamorín, SR: Heuréka.

Gábriš, T. 2017. Nový teoretický rámec behaviorálnej ekonomickej analýzy práva? [A New Theoretical Framework of Behavioural Economic Analysis of Law?], in Nedogmatická Právna Veda [Undogmatic Legal Science]. Od marxizmu po behaviorálnu ekonómiu. [From Marxism to Behavioral Economics]. Prague, Czech Republic: Wolters Kluwer.

Green, S. L. 2002. Rational Choice Theory: An overview. Baylor University: 2 - 72. https://business.baylor.edu/steve green/green1.doc

Henčeková, S. 2017. Od behaviorálnej k humanistickej analýze práva in Nedogmatická právna veda [From Behavioural to Humanistic Analysis of Law in Undogmatic Legal Science]. Od marxizmu po behaviorálnu ekonómiu [From Marxism to Behavioural Economics], Prague, Czech Republic: Wolters Kluwer.

Holcr, K. et al. 2011. Kriminológia [Criminology]. Prague, Czech Republic: Leges.

Houbová, D. et al. 2008. Psychologie pro právníky. [Psychology for Lawyers]. Plzeň, Czech Republic: Aleš Čeněk.

Kasinec, R. 2015. Právne princípy ako jednotiaci element právnych systémov [Legal principles as a unitary element of legal systems], Acta facultatis Iuridicae Universitatis Comenianae, 34 (no. 1).

Krajčovič, M. 2016. Nezávislost' súdnej moci z pohl'adu právneho princípu [Independence of the Judiciary in Terms of the Legal Principle], Justičná revue [Justice Review], 68 (no. 8 - 9).

Kolesár, J. 2010. Sankcie v trestnom práve [Penalties in criminal law]. Prievidza, Slovak Republic: Citicom.

L'orko, J.; Smalik, M. 2017. Úpadkové trestné činy a trestná zodpovednost' právnických osôb [Bankruptcy Offenses and Criminal Liability of Legal Persons], Acta Facultatis Iuridicae Universitatis Comenianae, 36 (extraordinary issue).

Materni, M. C. 2013. Criminal Punishment and the Pursuit of Justice, British Journal of American Legal Studies, 2: 263-304. https://hls.harvard.edu/content/uploads/2011/09/michele-materni-criminal-punishment.pdf

Mencerová, I.; Tobiášová, L.; Turayová, Y. et al. 2013. Substantive Criminal Law. General part. Šamorín, SR: Heuréka.

Mencerová, I.; Tobiášová, L.; Turayová, Y. et al. 2014. Substantive Criminal Law. Specific part. Šamorín, SR: Heuréka.

Pinz, J. 2011. Míra nezávislosti práva na zájmech společnosti. in Právo a jeho prostredie [The degree of the independence of law in the interests of society, in Law and its Environment], Bratislava, Slovak Republic: SAP.

Schmidtz, D. 2015. Prvky spravedlnosti [Elements of justice]. Prague, Czech Republic: Dokořán / CEVRO Institute.

Strémy, T. 2010. Majetková a ekonomická kriminalita a ich sociálne riziká [Property and economic crime and their social risks]. Trnava, SR: Typi Universitatis Tyrnaviensis.

Strémy, T.; Klátik, J. 2018. Alternatívne tresty. [Alternative penalties]. Bratislava, Slovak Republic: C.H. Beck.

Svatoš, R. 2014. Prevence kriminality [Crime Prevention]. České Budějovice, Czech Republic: University of European and Regional Studies.

Púry, F. 2015. Úpadkové trestné činy v Českej republike [Bankruptcy offenses in the Czech Republic]. Prague, Czech Republic: C.H. Beck. Urbanová, M. 2006. Systémy sociální kontroly a právo [Social Control Systems and Law]. Plzeň, Czech Republic: Aleš Čeněk. 


\section{The International Journal}

ENTREPRENEURSHIP AND SUSTAINABILITY ISSUES

ISSN 2345-0282 (online) http://jssidoi.org/jesi/

2018 Volume 6 Number 2 (December)

http://doi.org/10.9770/jesi.2018.6.2(10)

Večeřa, M. et al. 2013. Teória práva [Theory of Law]. $5^{\text {th }}$ expanded and supplemented edition. Bratislava, SR: EUROKÓDEX.

Večeřa, M.; Urbanová, M. 1996. Základy sociologie práva [Fundamentals of the Sociology of Law]. Second edition. Brno, Czech Republic: Masaryk University and publishing house Doplněk.

Žitňanská, L.; Ovečková, O. 2013. Obchodné právo [Business Law]. Obchodné Spoločnosti [Commercial companies]. $1^{\text {st }}$ volume. $2^{\text {nd }}$ supplemented and reworked edition, Bratislava, Slovakia: IURIS LIBRI.

Jozef ČENTÉŠ (prof., JUDr., PhD.) Graduated from the Faculty of Law of the Comenius University in Bratislava (1991), where he obtained a Ph.D. and the title of Associate Professor in Criminal Law. In 2014, after a successful appointment proceedings at Masaryk University in Brno, he was appointed a professor in criminal law science. He deals with substantive criminal law and criminal procedural law. He is the author (co-author) of the monograph Hmotnoprávne aspekty trestnej činnosti páchanej v súvislosti $\mathrm{s}$ nealkoholovou toxikomániou v Slovenskej republike [Substantive Law Aspects of Crime Related to Non-Alcoholic Drug Disorder in the Slovak Republic]. Bratislava (2007), Právne a inštitucionálne aspekty v boji proti legalizácii príjmov z trestnej činnosti ako integrálnej súčasti organizovanej kriminality [Legal and Institutional Aspects in Combating the Legalization of Income from Criminal Activity as an Integral Part of Organized Crime] (2010), Odpočúvanie - procesnoprávne a hmotnoprávne aspekty [Eavesdropping - Procedural and Substantive Aspects] (2013), History of Prosecution in Slovakia (2014). He is Deputy Director of the Criminal Department at the General Prosecutor of the Slovak Republic. He is Head of the Department of Criminal Law, Criminology and Criminalistics at the Faculty of Law of the Comenius University in Bratislava. He is a member of four scientific councils and two scientific boards of professional journals in the Czech Republic. He also acts as an external lecturer at the Judicial Academy of the Slovak Republic.

ORCHID ID: 0000-0003-3397-746X

Michal KRAJČOVIČ (Mgr.) Graduated from the Law Faculty of Comenius University in Bratislava in 2016. He graduated with a Master's degree with honours and was awarded the Academic Appreciation of the Dean of the Faculty of Law of the UK for an exemplary fulfilment of study duties during his studies. In the past, he completed an internship at the Supreme Court of the Slovak Republic and worked at the Executor's office of Mgr. Vladimír Cipár. At present he is a Ph.D. student at the Department of the Theory of Law and Social Sciences, the Faculty of Law of the Comenius University in Bratislava. During his studies he focuses on the field of criminal law, law theory, executive law and primarily active publishing activities. He is the author of several scientific articles. For a set of articles published in Judicial Review in the column Adspirantes legum he was awarded the Karol Plank student prize for 2015.

ORCHID ID: 0000-0002-4926-0714

Michal MRVA (JUDr., Mgr., PhD., LL.M) graduated from the Faculty of Law of the Comenius University in Bratislava in the field of law (2007), Faculty of Philosophy of the Comenius University in Bratislava in the field of Political Science (2008) and the Faculty of Business and Finance Law, University of Luxembourg in General European Law (2011). At the Faculty of Law of the Comenius University in Bratislava, he graduated in 2012 in the doctoral field of study "Theory and History of the State and Law". He is the author of several articles in both domestic and foreign scientific journals and publications. He focuses primarily on the issue of the theory of law, while he is a co-author of the monograph Interpretation and Argumentation in Law (2016). He is currently working as a professional assistant at the Department of the Theory of Law and Social Sciences at the Faculty of Law of Comenius University in Bratislava, and is concurrently a practising attorney.

ORCHID ID: 0000-0002-0741-5538

Register for an ORCID ID: https://orcid.org/register

Copyright (C) 2018 by author(s) and VsI Entrepreneurship and Sustainability Center This work is licensed under the Creative Commons Attribution International License (CC BY). http://creativecommons.org/licenses/by/4.0/

Open Access 